\title{
Multiple causes of male-killing in a single sample of the two-spot ladybird, Adalia bipunctata (Coleoptera: Coccinellidae) from Moscow
}

\author{
MICHAEL E. N. MAJERUS*†, J. HINRICH, G. V. D. SCHULENBURG $\dagger$ \\ \& ILIA A. ZAKHAROV \\ $\dagger$ Department of Genetics, Downing Street, Cambridge, U.K. and $¥$ Vavilov Institute of General Genetics, \\ Russian Academy of Sciences, Moscow, 117809 Russia
}

\begin{abstract}
Thirty-six matrilines from a single Muscovite sample of Adalia bipunctata were assayed, using appropriate primers, for presence of the four male-killing symbionts known to infect this species of ladybird. All four, a Rickettsia, a Spiroplasma and two different strains of Wolbachia, were found to be present. Vertical transmission efficiencies were assessed from $F_{1}$ and $F_{2}$ families from each of the matrilines, and were found to differ significantly between symbionts. Potential explanations of the presence of four different male-killing symbionts within a single population, are considered.
\end{abstract}

Keywords: Adalia bipunctata, Coccinellidae, inherited symbionts, male-killing, sex ratio, Wolbachia.

\section{Introduction}

Inherited symbionts that distort host reproduction to their own benefit are common in insects. One strategy is that of male-killing, in which male hosts are killed by the symbiont to the benefit of females infected with the same symbiont strain. Aphidophagous coccinellid beetles that lay eggs in clutches and in which neonate larvae indulge in sibling egg consumption have been identified as a group that is particularly prone to invasion by malekillers (Majerus \& Hurst, 1997). To date, maternally inherited female-biased sex ratios have been recorded in nine species of coccinellid (Lusis, 1947; Shull, 1948; Matsuka et al., 1975; Niijima \& Nakajima, 1981; Niijima, 1983; Hurst et al., 1992; 1997a; Majerus \& Hurst, 1997; Majerus et al., 1998; 1999a; Majerus \& Majerus, in press). These sex ratio biases have been shown or are assumed to result from male-killing symbionts, with a diverse array of bacteria being associated with the male-killing trait. In Adalia bipunctata, at least four different bacteria are known to cause male-killing: a Rickettsia (Werren et al., 1994), a Spiroplasma (Hurst et al., 1999b) and two strains of Wolbachia (Hurst et al., 1999c).

*Correspondence. E-mail: menm@mole.bio.cam.ac.uk (C) 2000 The Genetical Society of Great Britain.
Theoretical models of male-killers, based on vertical transmission efficiency, cost of infection borne by infected females and the level of fitness compensation (the benefit that accrues to surviving offspring of infected females as a result of the death of males), suggest that two or more male-killers cannot stably coexist in a single population (Hurst, 1991; Hurst et al., 1997b). As Randerson et al. (2000) have shown, the male-killer with the highest basic rate of increase (BRI), which is a product of the malekiller's vertical transmission efficiency, its direct costs on female bearers and the level of fitness compensation, will out-compete all others.

Despite this theoretical prediction, in several locations different male-killers reported from A. bipunctata are known to coexist. Thus, in Berlin, both the Rickettsia and the Spiroplasma coexist (Hurst et al., 1999b), while in Moscow, the Spiroplasma coexists with two strains of Wolbachia (Hurst et al., 1999c). Speculative explanation of such coexistence has hitherto considered hybrid zones between regions of pure infection, possibility of a transient situation consequent on recent secondary invasion and the possibility of host genes that affect the transmission efficiency of the male-killers (Hurst et al., 1999c). We here report analysis of male-killing in a single sample of $A$. bipunctata showing the coexistence of four different male-killers in this species and discuss the tenability of the theoretical explanations of malekiller coexistence. 


\section{Materials and methods}

\section{Phenotypic assaying of male-killing}

A sample of $110 \mathrm{~A}$. bipunctata was collected on 11 October 1997, from overwintering aggregations in a building near the Vavilov Institute of General Genetics, Gubkin Street, Moscow. The sample was transported to Cambridge in January 1998, where it was retained at $4^{\circ} \mathrm{C}$ until April. Approximately 100 ladybirds were then removed from the refrigerator, placed in clean stock Petri-dishes, fed initially on an artificial food (Majerus et al., 1989) for 2 days and thereafter on pea aphids, Acyrthosiphon pisum (Harris). Mating pairs where removed to individual Petri-dishes as they formed. In this way 40 mating pairs were isolated. These pairs were initially assayed for male-killer presence using two routine phenotypic indicators: egg hatch rates and progenic sex ratio (Hurst et al., 1992). In short, eggs were collected and counted from pairs daily, egg hatch rates were recorded, and resulting adults were sexed under $\mathrm{CO}_{2}$ anaesthetic.

$F_{1}$ crosses, using at least three females from each of the lines which produced a significantly female-biased sex ratio and males from normal lines, were set up to show that the female bias was inherited. Again egg hatch rates and progenic sex ratios were recorded. Vertical transmission rates for the different male-killers were assessed using progenic sex ratios from $F_{1}$ and $F_{2}$ crosses of matrilines shown to bear a male-killer.

\section{Identification of male-killing agents}

The respective symbionts were characterized using PCR assays specific for the known male-killing bacteria of A. bipunctata as described in Hurst et al. (1999c). Females with both low egg hatch rates and significantly female-biased progenic sex ratios were tested for each of the above-identified male-killing lineages. Genomic DNA was isolated from ovaries and subsequently subjected to PCR. For PCR tests, we used primers specific for the citrate synthase gene of male-killing Rickettsia (RICS741F: 5'-CATCCGGAGCTAATCCTTTTGC; RCIT1197R: 5'-CATTTCTTTCCATTGTGCCATC; cf. Davis et al., 1998), and for the ribosomal spacer region of Spiroplasmas of the $S$. ixodetis group (SPITS-J04: 5'-GCCAGAAGTCAGTGTCCTAACCG; SPITS-N55: 5'-ATTCCAAGGCATCCACCATACG; cf. Schulenburg et al. submitted). For identification of Wolbachia, we used the previously published primers for the wsp gene (primers wsp81F and wsp691R; Zhou et al., 1998). PCR suitability of genomic DNA preparations was checked via amplification of the mitochondrial cytochrome oxidase subunit I gene using insect-specific primers (Simon et al., 1994). Identities of Wolbachia strains were established by DNA sequencing. Amplified $w s p$ sequences were cloned and subsequently sequenced for both strands. Three clones per host specimen were analysed to guard against PCR errors. The generated sequences were thereafter compared to those of the two male-killing Wolbachia strains ' $\mathrm{Y}$ ' and ' $\mathrm{Z}$ ' which were previously isolated from $A$. bipunctata (formerly strains 'A' and 'B', respectively; now renamed in order to avoid confusion with nomenclature for the Wolbachia subgroups as both belong to same subgroup B). For details of molecular methods, see Hurst et al. (1999c).

\section{Results}

\section{Phenotypic assay for the male-killing trait}

Four of the 40 initial pairs failed to produce sufficient progeny for analysis. Of the remainder, six produced both low egg hatch rates $(<0.55)$ and significantly female-biased sex ratios (Table 1). All except two of the $\mathrm{F}_{1}$ families using females from these lines $(n=25)$ produced significantly female-biased sex ratios. The exceptions were one female of four from Mos 3, and one female of five from Mos 18, both of which produced high egg hatch rates and normal sex ratios.

\section{Identity of male-killing agents}

Female progeny from each of the six significantly female-biased matrilines amplified with one, and only one, of the primer pairs used. One line (Mos 3) amplified with the Rickettsia primers, three (Mos 9, Mos 33 and Mos 35) with the Spiroplasma primers, and two (Mos 6 and Mos 18) with the Wolbachia primers. DNA sequences of the wsp gene showed the Wolbachia from the two host lineages to be different. The wsp sequence isolated from line Mos 6 is identical to the strain " $Z$ " Wolbachia of $A$. bipunctata, whereas that for Mos 18 is identical to that of strain ' $Y$ '.

Table 1 Egg hatch rates and progenic sex ratios of lines of Adalia bipunctata showing the male-killing trait

\begin{tabular}{lccc}
\hline $\begin{array}{l}\text { Line } \\
\text { (+ male-killer) }\end{array}$ & $\begin{array}{c}\text { Egg hatch } \\
\text { rate }\end{array}$ & $\begin{array}{c}\text { No. of } \\
\text { progeny }\end{array}$ & $\begin{array}{c}\text { Sex } \\
\text { ratio } \dagger\end{array}$ \\
\hline Mos 3 (Rickettsia) & 0.478 & 34 & 0.147 \\
Mos 6 (Wolbachia 'Z') & 0.422 & 44 & 0.114 \\
Mos 9 (Spiroplasma) & 0.391 & 33 & 0 \\
Mos 18 (Wolbachia 'Y') & 0.444 & 43 & 0 \\
Mos 33 (Spiroplasma) & 0.511 & 35 & 0 \\
Mos 35 (Spiroplasma) & 0.388 & 18 & 0 \\
\hline
\end{tabular}

$\dagger$ Proportion male. 


\section{Vertical transmission efficiencies}

With the exclusion of the two revertant $F_{1}$ families, the vertical transmission rates, calculated as 1 - (the number of males produced divided by the number of females produced) (Hurst et al., 1993), were consistent between generations for individual matrilines, but varied considerably between matrilines (Table 2). There was significant heterogeneity between the sex ratios resulting from the four male-killers $\left(\chi_{3}^{2}=106.588, P<0.001\right.$ (summing the three Spiroplasma matrilines)), indicating variation in vertical transmission rates of the malekillers. Of further note, the vertical transmission efficiencies of the two strains of Wolbachia differed significantly $\left(\chi_{1}^{2}=17.563, P<0.001\right)$, the ' $\mathrm{Z}$ ' strain giving rise to proportionately more males than the ' $\mathrm{Y}$ ' strain.

\section{Discussion}

Consideration of the known geographical distributions of the four male-killer strains found in this single Muscovite sample make it highly unlikely that their coexistence represents a 'hybrid zone'. The $A$. bipunctata Rickettsia male-killer has been recorded from England, Germany and Denmark in Europe (Hurst et al., 1992; 1999b) and Kirgisia in Asia (Zakharov et al., 1998). Male-killing Spiroplasmas have been recorded in A. bipunctata from Central and Eastern European localities (Bielefeld, Bayreuth, Berlin, St. Petersburg, Moscow) (Hurst et al., 1999b), and from Asia (Tuva; Schulenburg et al. submitted). All of them have identical ribosomal spacer sequences (Schulenburg et al. submitted). The Rickettsia and Spiroplasma male-killers thus have wide geographical distributions which seem to overlap from Central Europe into Asian Russia. The two male-killing Wolbachia strains have been recorded from Moscow (Hurst et al., 1999c) and Tomsk (Zakharov and Schulenburg, pers. obs.).

A second hypothesis for coexistence is that the Muscovite population of $A$. bipunctata is heavily substructured and not panmictic as the models assume. For example, one might imagine a 'haystack model' in which local colonies exist with little migration between them. In such a situation, different male-killers may exist in matrilines adapted to different environmental conditions (e.g. different host plants). Studies of dispersion of A. bipunctata throughout the year argue strongly against heavy substructuring of populations. The typical pattern is of a dispersal flight in the spring, from overwintering sites away from host plants (usually in or on buildings). Initial activity in spring involves feeding on alternative foods and frequent flights in search of suitable essential prey (sensu Hodek, 1973). Once essential food has been found, mating and oviposition take place, females mating with many males during their reproductive life. Females move frequently during their reproductive period, both between patches of one type of host plant and different species of host plant, dispersal to new sites being initiated by the presence of coccinellid larvae (e.g. Hemptinne et al., 1992). Males follow females after a lag of a few days (Brakefield, 1984). At the end of the reproductive period, adults of one or more generations produced during the year disperse away from host plants to find suitable places to overwinter, often forming large overwintering aggregations (Majerus, 1994). The whole pattern is of a highly mobile well mixed population. Movement during the spring and summer is driven by the need to find suitable colonies of aphids, for which their is strong competition, both within the species, and with other predators and parasitoids. The differences in the pattern of usage of aphids on different species of host plants between different years (e.g. Majerus \& Kearns, 1989) argues against females being adapted to particular host plants.

A third hypothesis, that the coexistence of different male-killers results from very recent novel invasions of some of the male-killers into A. bipunctata, also seems untenable. In the case of the Rickettsia and the Spiroplasma, again the wide area of geographical overlap argues against either being of recent occurrence.

Table 2 Vertical transmission efficiencies from six matrilines bearing male-killing bacteria

\begin{tabular}{lcccl}
\hline Line & $\begin{array}{c}\text { Number } \\
\text { of families }\end{array}$ & $\begin{array}{c}\text { Total } \\
\text { progeny }\end{array}$ & $\begin{array}{c}\text { Sex ratio } \\
\text { (proportion } \\
\text { male) }\end{array}$ & $\begin{array}{c}\text { Mean vertical } \\
\text { transmission } \\
\text { efficiency } \pm \text { SE }\end{array}$ \\
\hline Mos 3 & 5 & 123 & 0.220 & $0.719 \pm 0.0166$ \\
Mos 6 & 6 & 222 & 0.126 & $0.856 \pm 0.0017$ \\
Mos 9 & 6 & 130 & 0.015 & $0.984 \pm 0.0006$ \\
Mos 18 & 7 & 168 & 0.012 & $0.988 \pm 0.0004$ \\
Mos 33 & 4 & 170 & 0.006 & $0.994 \pm 0.0001$ \\
Mos 35 & 5 & 199 & 0 & 1 \\
\hline
\end{tabular}

(c) The Genetical Society of Great Britain, Heredity, 84, 605-609. 
For the two male-killing strains of Wolbachia from A. bipunctata, phylogenetic analysis of $w s p$ sequences suggests that the two have a common origin but did not diverge recently (Hurst et al., 1999c). The most likely explanation is of a single, not recent origin of malekilling Wolbachia in A. bipunctata.

A fourth hypothesis, that host suppresser genes exist which differentially affect the transmission of the various male-killers is plausible and would help maintain the polymorphism (Randerson et al., 2000). However, an analysis of whether suppresser genes could maintain as many as four different male-killers within the same population seems inappropriate until evidence of the existence of such genes in coccinellids has been obtained.

None of these explanations of the coexistence of the four male-killers (and there may be more) in Muscovite A. bipunctata currently appears tenable. The unexpectedness of the coexistence of these four male-killers within a single population is consequent both upon models of male-killer population dynamics, and on the competitive exclusion principle.

To address the dichotomy between the observations of multiple male-killers contained herein and predictions made by models of the evolutionary dynamics of malekilling endosymbionts, future work should seek to: (i) verify the assumptions of the models; (ii) test the applicability of laboratory-generated data on vertical transmission efficiencies and direct costs on female hosts to field situations; (iii) determine whether there is any niche separation in the utilization of hosts by symbionts; (iv) monitor fluctuations in the prevalences of the four symbionts over time; and (v) determine whether all $A$. bipunctata individuals are equally susceptible to each of the male-killers.

Until potential variability in the interactions between the different male-killers and their hosts have been investigated, it is premature to view this as a case where the competitive exclusion principal is being compromised.

A detailed, field based, comparative analysis of the vertical transmission efficiency of the different malekillers, the occurrence of horizontal transmission, and the fitness benefits that accrue to surviving larvae of male-killed clutches for each symbiont, will be needed to assess levels of niche separation between these symbionts and solve the conundrum of the presence of multiple male-killer agents in A. bipunctata.

\section{Acknowledgements}

We acknowledge with thanks, technical assistance from Dominique Bertrand, Roger Day, Denis Farrington and Tamsin Majerus. The work was supported in part by a studentship from the Commission of the European
Communities (ERBFMBICT960614) to JHGvdS. I.A.Z. was supported by the Russian Foundation of Basic Research (Grants 99-04-48193 and 96-15-97781).

\section{References}

BRAKEFIELD, P. M. 1984. Ecological studies on the polymorphic ladybird Adalia bipunctata in the Netherlands. II Population dynamics, differential timing of reproduction and thermal melanism. J. Anim. Ecol., 53, 775-790.

DAVIS, M. J., YING, Z., BRUNNER, B. R., PANTOJA, A. AND FERWERDA, F. H. 1998. Rickettsial relative associated with Papaya bunchy top disease. Current Microbiol., 26, 80-84.

HEMPTINNE, J.-L., DiXoN, A. F. G. AND COFFIN, J. 1992. Attack strategy of ladybird beetles (Coccinellidae): Factors shaping their numerical response. Oecologia, 90, 238-245.

HODEK, I. 1973. Biology of Coccinellidae. Academia, Prague.

HURST, L. D. 1991. The incidences and evolution of cytoplasmic male-killers. Proc. Roy. Soc. B, 244, 91-99.

HURST, G. D. D., MAJERUS, M. E. N. AND WALKER, L. E. 1992. Cytoplasmic male killing elements in Adalia bipunctata (Linnaeus) (Coleoptera: Coccinellidae). Heredity, 69, 84-91.

HURST, G. D. D., MAJERUS, M. E. N. AND WALKER, L. E. 1993. The importance of cytoplasmic male killing elements in natural populations of the two spot ladybird, Adalia bipunctata (Linnaeus) (Coleoptera: Coccinellidae). Biol. J. Linn. Soc., 49, 195-202.

HURST, G. D. D., HAMMARTON, T. M., BANDI, C., MAJERUS, T. M. O., BERTRAND, D. AND MAJERUS, M. E. N. 1997a. The diversity of inherited parasites of insects: the male-killing agent of the ladybird beetle Coleomegilla maculata is a member of the Flavobacteria. Genet. Res., 70, 1-6.

HURST, G. D. D., HURST, L. D. AND MAJERUS, M. E. N. 1997 b. Cytoplasmic sex-ratio distorters. In: O’Neill, S. L., Hoffmann, A. A. and Werren, J. H. (eds) Influential Passengers, pp. 125-154. Oxford University Press, Oxford.

HURST, G. D. D., BANDI, C., SACCHI, L., COCHRANE, A. G., BERTRAND, D., KARACA, I. ET AL. 1999a. Adonia variegata (Coleoptera: Coccinellidae) bears maternally inherited Flavobacteria that kill males only. Parasitology, 118, 125-134.

HURST, G. D. D., SCHUlenburG, J. H. G. V. D., MAJERUS, T. M. O., BERTRAND, D., ZAKHAROV, I. A., BAUNGAARD, J. ET AL. 1999b. Invasion of one insect species, Adalia bipunctata, by two different male-killing bacteria. Insect Mol. Biol., 8, 133-139.

HURST, G. D. D., JiGGins, F. M., SCHULENBURG, J. H. G. V. D., BERTRAND, D., WeSt, S. A., GORIACHEVA, I. I. ET $A$ L. 1999c. Male-killing Wolbachia in two species of insects. Proc. Roy. Soc. B, 266, 735-740.

LUSIS, J. J. 1947. Some rules of reproduction in populations of Adalia bipunctata: non-male strains in populations. Dokl. Akad. Nauk SSSR, 57, 951-954.

MAJERUS, M. E. N. 1994. Ladybirds, no. 81, New Naturalist Series. HarperCollins, London.

MAJERUS, M. E. N. AND HURST, G. D. D. 1997. Ladybirds as a model system for the study of male-killing symbionts. Entomophaga, 42, 13-20. 
MAJERUS, M. E. N. AND KEARNS, P. W. E. 1989. Ladybirds, Naturalists' Handbook no. 10. Richmond Publishing, Slough, UK.

MAJERUS, M. E. N. AND MAJERUS, T. M. O. 1999. Female biased sex ratio due to male-killing in the Japanese ladybird, Coccinula sinensis (Coleoptera: Coccinellidae). Ecol. Ent., 25, 1-5.

MAJERUS, M. E. N., KEARNS, P. W. E., FORGE, H. AND IRELAND, H. 1989. Ladybirds as teaching aids: 1 Collecting and culturing. J. Biol. Ed., 23, 85-95.

MAJERUS, T. M. O., MAJERUS, M. E. N., KNOWLES, B., WHEELER, J., BERTRAND, D., KUZNETZOV, V. N. ET AL. 1998. Extreme variation in the prevalence of inherited male-killing microorganisms between three populations of the ladybird Harmonia axyridis (Coleoptera: Coccinellidae). Heredity, 81, 683-691.

MATSUKA, M., HASHI, H. AND OKADA, I. 1975. Abnormal sex ratio found in the lady beetle Harmonia axyridis Pallas (Coleoptera: Coccinellidae). Appl. Entomol. Zool., 10, 84-89.

NIIJIMA, K. 1983. Experimental transfer of abnormal sex ratio in two ladybird species. Bull. Fac. Agric. Tamagawa University, 23, 11-17.

NIIJIMA, K. AND NAKAJIMA, K. 1981. Abnormal sex ratio in Menochilius sexmaculatus (Fabricius). Bull. Fac. Agric. Tamagawa University, 21, 59-67.
RANDERSON, J. P., SMITH, N. G. C. AND HURST, L. D. 2000. The evolutionary dynamics of male-killers and their hosts. Heredity, 84, 152-160.

SCHULENBURG, J. H. G. V. D., MAJERUS, T. M. O., DORZHU, C. M., ZAKHAROV, I. A., HURST, G. D. D. AND MAJERUS, M. E. N. Submitted. Evolution of male-killing Spiroplasma bacteria inferred from ribosomal spacer sequences.

SHULL, H. F. 1948. An all-female strain of lady beetles with reversions to normal sex ratio. Am. Nat., 82, 241-251.

SIMON, C., FRATI, F., BECKENBACK, A., CRESPI, B., LIU, H. AND FLOOK, P. 1994. Evolution, weighting and phylogenetic utility of mitochondrial gene sequences and a compilation of conserved polymerase chain reaction primers. Ann. Ent. Soc. Amer., 87, 651-701.

WERREN, J. H., HURST, G. D. D., ZHANG, W., BREEUWER, J. A. J., STOUTHAMER, R. AND MAJERUS, M. E. N. 1994. Rickettsial related male-killing in the ladybird beetle (Adalia bipunctata). J. Bacteriol., 176, 388-394.

ZAKHAROV, I. A., GORYACHEVA, I. I., RYDKINA, E. B., ROUX, V. AND RAOULT, D. 1998. Cytoplasmically inherited femalebiased sex ratio in Kyrgyz population of Adalia bipunctata turanica caused by bacteria of the genus Rickettsia. Russian J. Genet., 34, 171-175.

ZHOU, W. G., ROUSSET, F. AND O'NEILL, S. L. 1998. Phylogeny and PCR-based classification of Wolbachia strains using wsp gene sequences. Proc. R. Soc. B., 265, 509-515. 